\title{
Study of Biological Methods in Landfill Leachate Treatment
}

\author{
Parna Eskandari Payandeh ${ }^{1}$, Naser Mehrdadi ${ }^{2}$, Parisa Dadgar ${ }^{3}$ \\ ${ }^{1}$ Graduate Department of Civil and Environmental Engineering, University of Tehran, Aras International Campus, Jolfa, Iran \\ ${ }^{2}$ Graduate Faculty of Environment, University of Tehran, Tehran, Iran \\ ${ }^{3}$ Graduate Department of Environmental Engineering, Central Tehran Branch, Islamic Azad University, Tehran, Iran \\ Email: *p.payandeh@ut.ac.ir
}

How to cite this paper: Payandeh, P.E., Mehrdadi, N. and Dadgar, P. (2017) Study of Biological Methods in Landfill Leachate Treatment. Open Journal of Ecology, 7, 568580 .

https://doi.org/10.4236/oje.2017.79038

Received: June 28, 2017

Accepted: August 15, 2017

Published: August 18, 2017

Copyright (C) 2017 by authors and Scientific Research Publishing Inc. This work is licensed under the Creative Commons Attribution International License (CC BY 4.0).

http://creativecommons.org/licenses/by/4.0/

Open Access

\begin{abstract}
Landfill leachate is mainly the result of precipitation of water into the layers of buried waste, and biochemical reactions of waste that has dangerous substances and pollutants that lead to the contamination of surface and groundwater resources. Therefore, it must be collected and treated properly. The investigation of various biological methods in leachate treatment, their advantages and disadvantages, and their effect on reduction of COD (chemical oxygen demand) are the objectives of this study. Reviewed processes include anaerobic and aerobic sequencing batch reactor, up-flow anaerobic sludge blanket, moving-bed biofilm reactor, membrane bioreactor, and aerated lagoons, lead to reduction of biodegradability pollutants in different circumstances. The present study has indicated that the most and the least reduction of COD has been through aerated lagoon (95\%) and moving-bed biofilm reactor $(8 \%)$, respectively.
\end{abstract}

\section{Keywords}

Biological Treatment, COD, Leachate, Landfill, Solid Waste

\section{Introduction}

In recent decades, increasing population, industrialization and excessive consumption by humans, has increased waste production significantly [1]. Based on the sustainable development system, the last element required in solid waste management is landfilling. Modern landfill is known as a method of solid waste disposal on land without causing any harm or danger to public health [2]. The main problem of solid waste landfills is the production of leachate and biogas due to decomposition of organic waste compounds [3]. However, mismanage- 
ment of solid wastes, and deficient development (non-engineered) of landfills result in soil and groundwater contamination due to leachates generated there [4]. Leachate is mainly the result of precipitation of water into the layers of buried waste and biochemical reactions of waste [5]. For this reason, leachate is contaminated with hazardous substances and pollutants such as ammonia nitrogen, organic matter, heavy metals and toxic materials that pollute surface and groundwater resources and will result in various environmental pollutions which endanger human health [6]. Landfills have been distinguished as one of the significant dangers to groundwater resources all through the world [7]. At present, due to strict environmental rules in particular on surface and groundwater along with the need for reusing water, landfill leachate treatment is necessary. Therefore, the best method of controlling pollution and environmental hazards by leachate is leachate treatment in order to remove harmful substances before being discharged into water resources [8]. Composition features of municipal waste in Iran, includes the high percentage of corruptible materials and moisture, as well as specific climatic conditions such as low rainfall and high evaporation caused the leachate has a high pollution load, in comparison with industrial countries [3]. Leachate features and compounds depending on the type and density of waste, pattern of rainfall, hydrology of landfill, biochemical reactions and age of the landfill, are variable. With increasing age of the landfill, due to the degradation of bio-degradable compounds and remain of non-biodegradable part of COD, the BOD (biological oxygen demand)/COD ratio is reduced $(<0.3)$. Young leachate contains high concentration of organic compounds such as volatile fatty acids (VFA) and has higher level of BOD/COD ratio (>0.3). In treating young leachate, biological methods (anaerobic and aerobic processes), due to their easy operations and low cost, are used commonly. The treatment of old leachate (due to the resistant compounds to biodegradation) is a challenging problem that needs to integrate the appropriate methods [1].

\section{Materials and Methods}

\subsection{Biological Treatment}

Biological processes are highly effective in the treatment of young landfill leachate, while their impact is reduced in old leachate treatment due to the resistance of contaminants to biodegradation [9]. The effect of biological treatment depends on factors such as treatment conditions, temperature, $\mathrm{pH}$, type of microorganisms, and food. Biological treatment methods are divided into aerobic and anaerobic categories [8].

\subsubsection{Anaerobic Biological Treatment}

This process involves the biological degradation of organic and inorganic materials in the absence of oxygen [10] and consists of two phases: the first phase is the acidic phase in which microorganisms convert the organic material into organic acids. In the second phase, anaerobic microorganisms convert volatile or- 
Table 1. Advantages and disadvantages of anaerobic system.

\begin{tabular}{cc}
\hline Disadvantages & Advantages \\
\hline Heavy metals can prevent digestion & $\begin{array}{c}\text { Lower dosage of phosphorus required as } \\
\text { a growth factor for anaerobic bacteria } \\
\text { Lower excess sludge production }\end{array}$ \\
$\begin{array}{c}\text { Sensitive to changes in temperature and } \mathrm{pH} \text {, as well } \\
\text { as various toxic substances existing in influent of the } \\
\text { reactor or byproducts produced in the reactor }\end{array}$ & Lower energy usage \\
$\begin{array}{c}\text { Remain high concentration of ammonia in effluent } \\
\text { Long time for start up }\end{array}$ & Removal of more than 90\% of BOD \\
\end{tabular}

ganic acids into carbon dioxide $\left(\mathrm{CO}_{2}\right)$ and methane $\left(\mathrm{CH}_{4}\right)$ [8]. The main advantages and disadvantages of anaerobic systems during landfill leachate treatment are shown in Table 1 [8] [9]. The most common anaerobic reactors applied to leachate treatment include anaerobic sequencing batch reactor, and up-flow anaerobic sludge blanket.

\section{1) Anaerobic sequencing batch reactor}

Anaerobic sequencing batch reactor (ASBR) process can be seen as a suspended growth process with reaction and solid-liquid separation operations in a pond, similar to sequencing aerobic reactor (SBR). ASBR includes four steps: a) feeding, b) reaction, c) sedimentation, d) discharge/effluent discharge. During the reaction, the mixing is done intermittently for a few minutes every hour to ensure uniform distribution of nutrients and solids. Biological reactions start during feeding stage. After the feeding, with any concentration of micro-organisms, $\mathrm{F} / \mathrm{M}$ (food to microorganism) ratio is high, which provides the driving force for metabolic activity and converting waste into biogas [11]. The principal performance of the mentioned system is to produce large amounts of methane by anaerobic fermentation and remove organic matter [12].

\section{2) Up-flow anaerobic sludge blanket}

Up-flow anaerobic sludge blanket (UASB) is a modern anaerobic treatment process that can have high efficiency and little hydraulic retention time (HRT) [13]. Among the reactors with the ability to accept high pollution loads, UASB reactor has the most application in industrial, pilot plant and laboratory scale throughout the world [14]. UASB process is more efficient in the leachate treatment at concentration of higher than $800 \mathrm{mg} / \mathrm{L}$ and $\mathrm{BOD} / \mathrm{COD}$ ratio (biological degradation) more than 0.3 [15].

\subsubsection{Aerobic Biological Treatment}

Aerobic treatment results in the removal of biodegradable organic pollutants and nitrification of ammonium nitrogen $\left(\mathrm{NH}_{3}-\mathrm{N}\right)$ [13]. In aerobic systems, microorganisms do purifying actions in the presence of dissolved oxygen. Therefore, in all aerobic systems, sufficient dissolved oxygen must be available to microorganisms that are generally done by aeration devices. Also, using Oxygena- 
tion, mixing or stirring the contents of the reactor or aeration tank is done by aeration devices in order to create a contact between microorganisms and wastewater. Anaerobic leachate treatment system (such as treatment of wastewater) is classified into two broad categories "suspended growth methods" and "attached growth methods" [16].

\section{1) Aerobic biological treatment-attached growth system}

In this way, microorganisms, as a biofilm or microbial membrane, operate snugly on the solid surface inside the reactor. The solid body is called Media and is made of stone, sand, ash, plastic and other synthetic materials. Attached growth systems are either fixed (completely submerged) or float (some parts inside the fluid and the other parts outside the fluid in the air) [17]. Advantages and disadvantages of aerobic-attached growth system are shown in Table 2 [8]. Attached-growth biological systems examined in this study include: Moving-bed biofilm reactor (MBBR), membrane bioreactor (MBR).

\section{a) Moving-bed biofilm reactor}

Moving-bed biofilm reactor process is based on the use of suspended polymer (plastic) carriers which continuously move inside the aerobic tank and active biomass grows on its surface [13]. The most important feature of such reactors is microorganisms stuck to the bed without being washed with the flow. This will increase the concentration of microorganisms in the system. In comparison with activated sludge process, most biofilm reactors are resistant to toxic substances and environmental changes due to the high concentration of microorganisms. The advantages of this method are: high concentration of biomass, low sludge settling time, less sensitive to toxic substances, removal of organic substances, and ammonia in a single process [16].

\section{b) Membrane bioreactor}

Membrane bioreactor systems is a combination of biological (by the bioreactor) and physical (separation of water from solids by membrane) process [18]. In

Table 2. Advantages and disadvantages of aerobic-attached growth system.

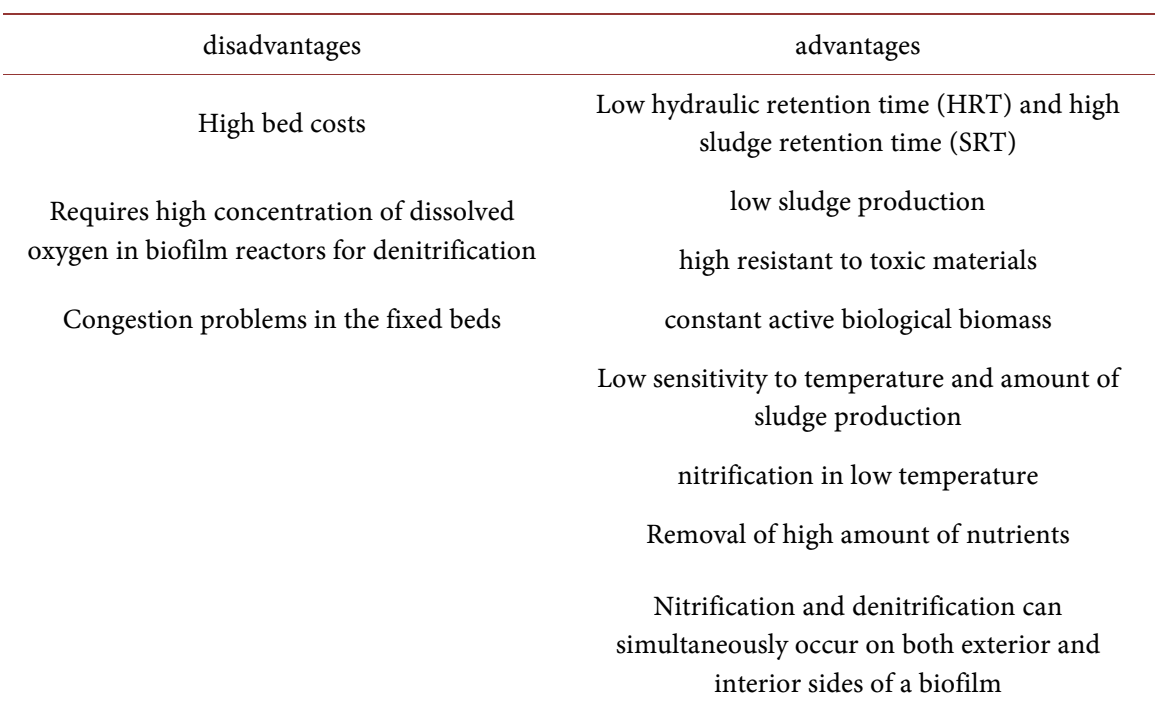


the membrane bioreactor process, aerobic bioreactor unit, through supplying oxygen leads to COD oxidation and nitrification and anoxic unit in the absence of oxygen leads to denitrification. The MBR System with high sludge retention time (SRT) leads to the growth of nitrifying bacteria that has significant influence on the nitrification process [9]. Membrane bioreactors are known as systems with high energy needs, $10-20 \mathrm{~kW}{ }^{\star} \mathrm{h} / \mathrm{m}^{3}$. Despite high operating costs, membrane bioreactor systems are effective alternative methods in leachate treatment [19]. The combination of nanofiltration and membrane bioreactor, are suggested as a reliable method in old leachate treatment [1]. The membrane bioreactor is widely used in landfill leachate treatment due to its high performance in the removal of ammonia. The effluent of this system contains compounds resisting to biodegradation (such as humic substances, and a little amount of ammonia and heavy metals) for which advanced oxidation processes (AOPs) are amongst suitable treatment methods [20]. The Advantages of this method are less sludge production, effluent of high quality, high concentration of nitrifying bacteria, and effective performance of nitrification could be mentioned [1]. The reactor also has disadvantages such as high initial investment and running costs (due to the short lifespan of membranes and also their need for maintenance and cleaning) [16].

\section{2) Aerobic biological treatment-suspended growth system}

a) Sequencing batch reactors

In this type of treatment system, all stages including aerobic treatment, sludge settling and clarification are done in a tank. Sequencing batch reactor (SBR) treatment system is less affected by changes in the amount of organic load and ammonium nitrogen concentration. Despite the good performance and the flexibility of this system, its usage produces large volumes of sludge and poor clarification [8]. Because of the fact that this system provides an operation regime compatible with organic carbon oxidation as well as nitrification, it is appropriate for nitrification-denitrification processes [13]. SBR process is effective for removing organic biodegradable compounds, while solid suspended particles result in the clogging of the system. Therefore, it results in poor quality effluent [21].

\section{b) Aeration Lagoon}

One of the easiest processes in landfill leachate treatment is aerated Lagoon, which are aerated through surface aerators or deep aeration diffuser. In this way, the process occurs chemically, and using biological oxidation [22]. Basically, an aerated Lagoon (stabilization pond) with a depth of $1-2$ meters is dug and designed like a natural lake. Upper part of the lagoon is aerobic that reduced compounds are oxidized in lower parts [8].

\section{Results and Discussions}

\subsection{Anaerobic Sequencing Batch Reactor Performance}

According to investigations, raw leachate can be treated well in this system. Re- 


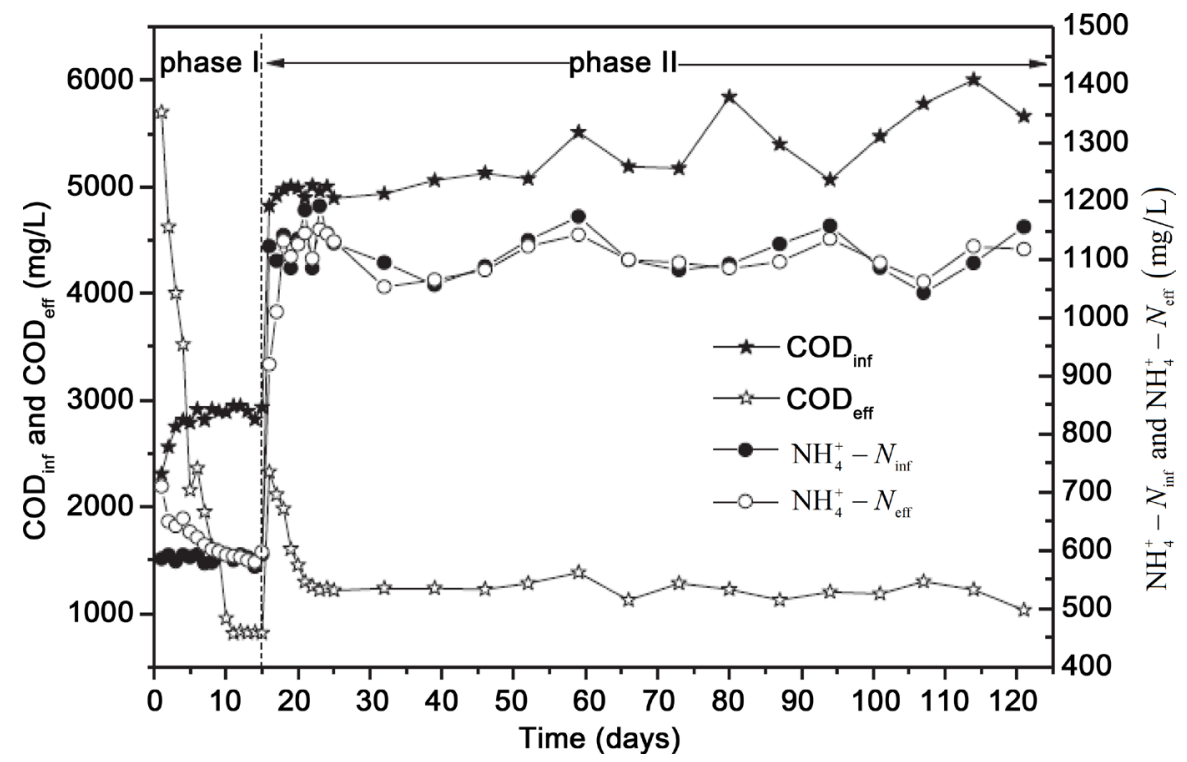

Figure 1. COD and $\mathrm{NH}_{4}-\mathrm{N}$ Changes over time in anaerobic sequencing batch reactor.

moval of $64 \%-85 \%$ of COD (the initial concentration of $17,000 \mathrm{mg} / \mathrm{L}$ ) in volume and specific loading rate, which is variable between $0.4-9.4$, is possible. Approximately, $83 \%$ of the removed COD is converted to methane and the rest is converted to sludge [11]. In another study, anaerobic sequencing batch reactor process with organic loading rate of $5 \mathrm{~kg} / \mathrm{m}^{3} /$ day leads to the removal of $80 \%$ of COD (with initial concentration of $6000 \mathrm{mg} / \mathrm{L}$ ). As seen in Figure 1, at the beginning of the treatment, the concentration of COD and $\mathrm{NH}_{4}-\mathrm{N}$ was higher in the effluent than influent, which may be the result of microbial hydrolysis. From the tenth day of the treatment, sodium phosphate is adapted well to the ASBR system, and COD concentration dropped to $65 \%$. While the concentration of $\mathrm{NH}_{4}-\mathrm{N}$ has reduced and became equal to its concentration in the effluent. The constant COD amount by $70 \%$ in the next 5 days represents the successful launch of ASBR system. From the days $16^{\text {th }}$ to $120^{\text {th }}$ (Phase 2), it has resulted in the removal of organic compounds of the leachate and energy recycling. In this phase, at first COD removal efficiency decreased then increased rabidly to $80 \%$, and this rate has remained stable for 7 days [12].

\subsection{Up-Flow Anaerobic Sludge Blanket (UASB) Performance}

In a study, by the use of UASB process, the maximum COD removal efficiency with organic loading rate of $5 \mathrm{~g} / \mathrm{L} /$ day, was $71 \%$ and no reduction in the amount of $\mathrm{NH}_{4}-\mathrm{N}$ was reported. Furthermore, the study has shown that the effluent of UASB reactor is not suitable for use in the environment [15]. According to the results of another study, maximum COD removal rate has been reported $87 \%$ in a condition where organic loading rate was $12 \mathrm{~g} \mathrm{COD/L/day,} \mathrm{and} \mathrm{maximum}$ reactor performance temperature was $38^{\circ} \mathrm{C}$. According to some results, it is necessary to use aerobic treatment plant for final treatment of the effluent of the reactor in order to achieve national standards for the disposal of wastewater 


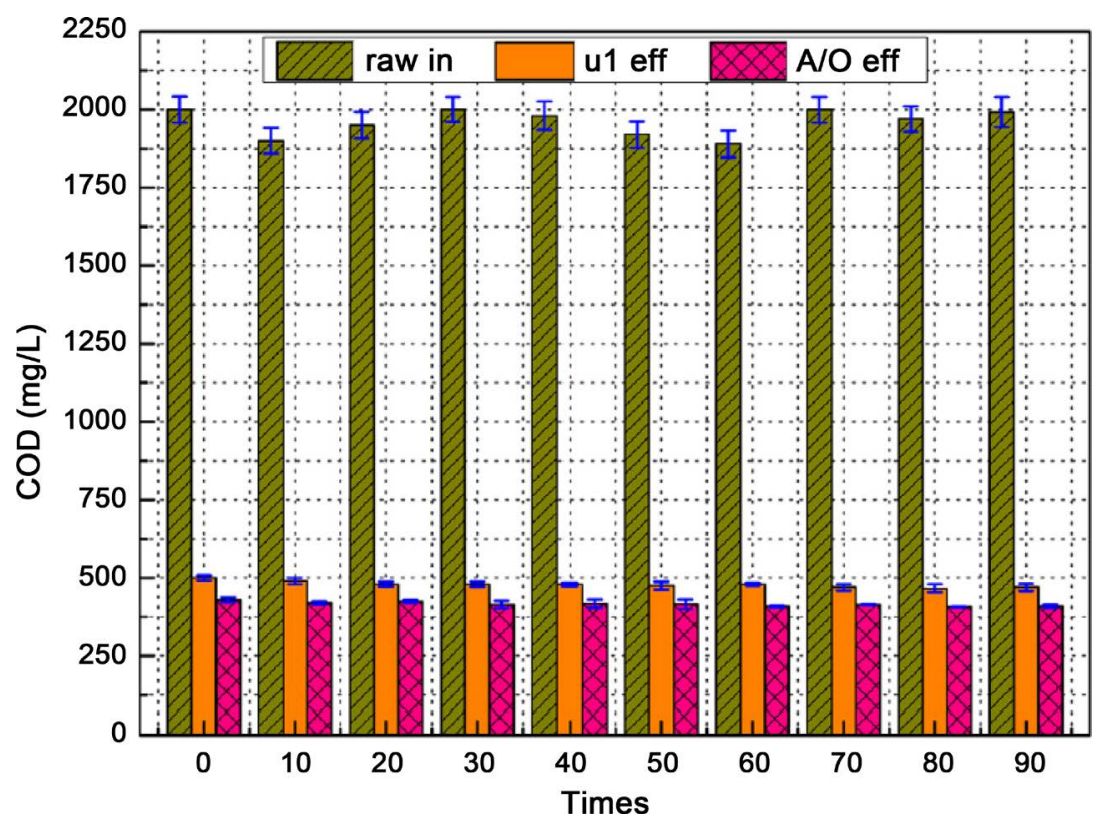

Figure 2. COD changes over time.

[14]. Wu et al., concluded that by the use of UASB, COD of diluted leachate (the initial concentration of $6000 \mathrm{mg} / \mathrm{L}$ before dilution) can be decreased from 2050 to $465 \mathrm{mg} / \mathrm{L}$ (77\%). As shown in Figure 2, the concentration of COD in the effluent of aerobic/anaerobic UASB reactor was 450 - 480 and $410-430 \mathrm{mg} / \mathrm{L}$, respectively. The organic loading rate has been reported $0.1 \mathrm{~kg} / \mathrm{m}^{3} /$ day [23].

\subsection{Moving-Bed Biofilm Reactor Performance}

Moving-bed biofilm reactor performance is an effective method for the biological treatment of landfill leachate. $90 \%$ nitrogen and 20\% COD have been removed. The high degree of nitrogen removal can be achieved in a high volume of nitrification and denitrification [24]. In another study, Chen et al., concluded that MBBR reactor as a basic mechanism can continuously lead to $97 \%$ ammonium removal by microbial absorbing and nitrification along with the retention time of 1.5 days as the basic mechanism [25]. COD removal has been analyzed in moving bed biofilm reactor in three stages according to Figure 3. First step is considered as start-up phase or unstable phase to adapt microorganisms to the leachate and increase the loading rate. By increasing the COD organic load, COD concentration in the effluent of anaerobic and aerobic MBBR declined. On $24^{\text {th }}$ day, COD removal efficiency reached to $90 \%$ which represents the complete start-up of anaerobic-aerobic MBBR system. The second and third stages can be considered as sustainable processes. In the second phase, the HRT of anaerobic MBBR firstly decreased from 4 to 2.5 days and then to 1.5 days with the same COD concentration $(16,000 \mathrm{mg} / \mathrm{L})$ dropped, and results in the increase of organic loading rate of COD from 4 to 6.4 and then to $10.67 \mathrm{~kg} \mathrm{COD} / \mathrm{m}^{3} /$ day. It can be concluded that HRT has a significant impact on the performance of MBBR system. The average output COD from anaerobic MBBR system increased from 


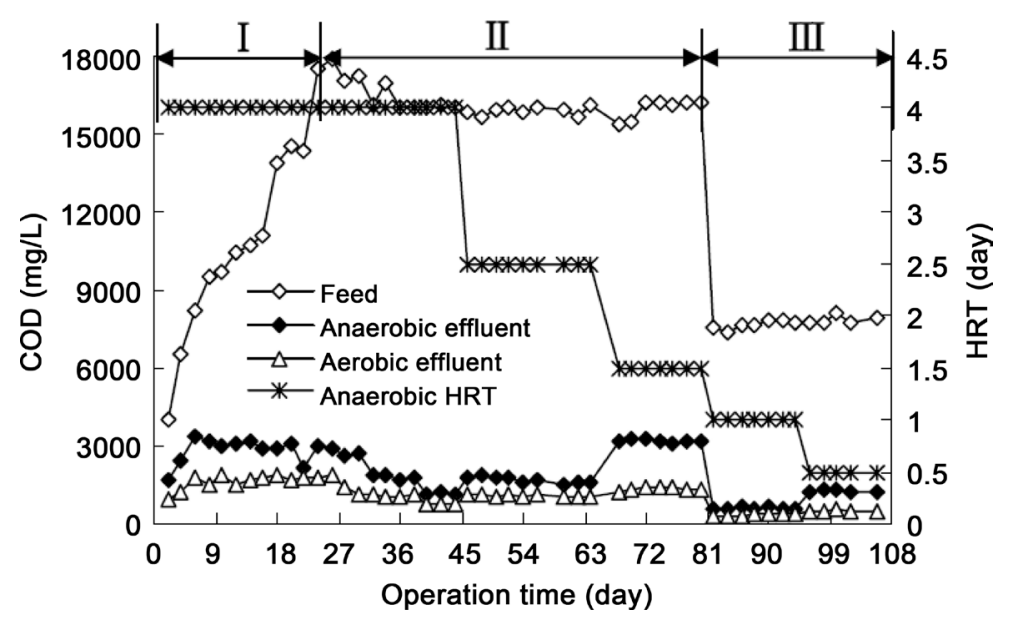

Figure 3. COD removal in aerobic-anaerobic moving-bed biofilm reactor.

1526 to 3182 and then $1586 \mathrm{mg} / \mathrm{L}$, and the average output COD from aerobic MBBR increased from 938 to 1045 and then to $1318 \mathrm{mg} / \mathrm{L}$. The total COD removal efficiency declined from $94 \%$ to $92 \%$. Anaerobic MBBR system played an important role in the removal of COD which reduced the total COD from $91 \%$ to $80 \%$. Aerobic MBBR increased COD removal efficiency from $3 \%$ to $12 \%$. By reducing anaerobic HRT from 4 to 2.5 days, minor changes occurred in the removal of COD in both reactors. In the third stage, along with the reduction of HRT, organic loading rate is increased. Average COD output from anaerobic and aerobic MBBR system increased from 578 to 1134 and from 347 to 471 $\mathrm{mg} / \mathrm{L}$, respectively. The total COD removal efficiency declined from $95 \%$ to $94 \%$. The total COD removal rate in anaerobic MBBR system decreased from $92 \%$ to $86 \%$ and in aerobic MBBR has increased from $3 \%$ to $8 \%$. The results have indicated that the anaerobic-aerobic system can be effective in leachate treatment [25].

\subsection{Membrane Bioreactor Process Performance}

During an investigation, membrane bioreactor system with aeration rate of $35 \mathrm{~g}$ $\mathrm{O}_{2} / \mathrm{m}^{2} /$ day resulted in $80-83 \%$ reduction of COD with initial concentration of $1000-3000 \mathrm{mg} / \mathrm{L}$ [26]. In another study, membrane bioreactor with organic rate of $1.2 \mathrm{~g} \mathrm{COD/L/day} \mathrm{and} \mathrm{SRT} \mathrm{of} 80$ days leads to COD and ammonia removal to $63 \%$ and $98 \%$ with initial concentration of 1550 and $288 \mathrm{mg} / \mathrm{L}$, respectively. Under the condition that the HRT is equal to 12 hours and the concentration of ammonia is high $(6 \mathrm{C} / \mathrm{N})$, biodegradation of phenols and phthalates has increased, while a retention time of 24 hours is required for decomposition of pharmaceutical compounds. The high ratio of ammonia $(6 \mathrm{C} / \mathrm{N})$ promotes the growth of bacteria and thus increases the quality of the treatment. This process resulted in a reduction of more than $80 \%$ of COD and ammonia nitrogen with initial concentrations of 14,000 and $360 \mathrm{mg} / \mathrm{L}$, respectively [27]. With the gradual increase of the HRT, organic loading rates increased and resulted in the production of excess sludge. Sludge retention time has decreased in order to 


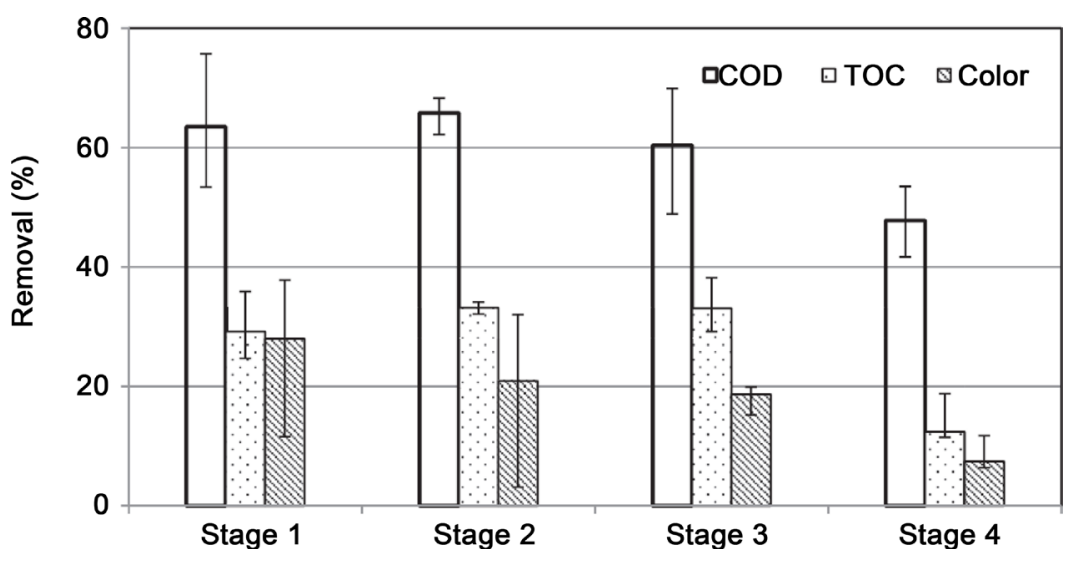

Figure 4. Membrane bioreactor performance in COD, TOC and paint removal.

control the deposition rate. In the fourth stage, with increasing HRT, the proportion of microorganisms to food increased more than normal and resulted in unstable operations. According to Figure 4, the maximum removal of COD, total organic carbon (TOC) and paint with HRT of 32 hours and SRT of 160 days were $66 \%, 33 \%$ and $21 \%$, respectively. Although nitrification started up in HRT of 18 hours, the membrane bioreactor performance, due to high organic loading rates (2.1 g COD/L/day), decreased. The operation conditions are: (first stage: 20 days operation time, 44 hours HRT, 200 days SRT, organic loading rate of $0.9 \mathrm{~g}$ $\mathrm{COD} / \mathrm{L} /$ day, the $\mathrm{F} / \mathrm{M}$ rate $0.1 \mathrm{~kg} \mathrm{COD} / \mathrm{kg} \mathrm{VS}$ (volatile solids)/day), (second stage: 14 days operation time, 32 hours HRT, 160 days SRT, organic loading rates of $1.3 \mathrm{~g} \mathrm{COD} / \mathrm{L} /$ day, the $\mathrm{F} / \mathrm{M}=0.1 \mathrm{~kg} \mathrm{COD} / \mathrm{kg} \mathrm{VS} /$ day), (third stage: 14 days operation time, 24 hours HRT, 50 days SRT, organic loading rate of $1.5 \mathrm{~g}$ $\mathrm{COD} / \mathrm{L} /$ day, the $\mathrm{F} / \mathrm{M}=0.1 \mathrm{~kg} \mathrm{COD} / \mathrm{kg} \mathrm{VS} /$ day), (the fourth stage: 14 days operation time, 18 hours HRT, the SRT of 35 days, organic loading rate of $2.1 \mathrm{~g}$ $\mathrm{COD} / \mathrm{L} /$ day, the $\mathrm{F} / \mathrm{M}$ to $0.2 \mathrm{~kg} \mathrm{COD} / \mathrm{kg} \mathrm{VS} /$ day [20].

\subsection{Aerobic Sequencing Batch Reactor Process Performance}

SBR process, with the amount of 2.5 to $4 \mathrm{mg} / \mathrm{L}$ dissolved oxygen and $\mathrm{pH} 6.5$ 8.5 , eliminates $87 \%$ of COD and $96 \%$ of $\mathrm{NH}_{3}-\mathrm{N}$, with the initial concentrations of 4000 and $2000 \mathrm{mg} / \mathrm{L}$, respectively [21]. In another study, the use of aerobic reactor within 7 days resulted in the removal of $30 \%$ and $65 \%$ of COD and ammonia nitrogen with the initial concentrations of 3200 and $1800 \mathrm{mg} / \mathrm{L}$, respectively. By adding zeolite, the removal of COD and ammonia nitrogen declined to $43 \%$ and $96 \%$, respectively. According to Figure 5, SBR systems reduced the concentration of COD from 3150 to $2224 \mathrm{mg} / \mathrm{L}$ (30\%) [28].

\subsection{Aerated Lagoon Process Performance}

Using aerated lagoons results in the removal of 80 and $75 \%$ ammonia and COD with initial concentration of 965 and $1740 \mathrm{mg} / \mathrm{L}$ removed from old landfill leachate during long retention time between 11 and 254 days, respectively. Partial of $80 \%$ removal of nitrogen in aerated Lagoon was done by ammonia evapora- 


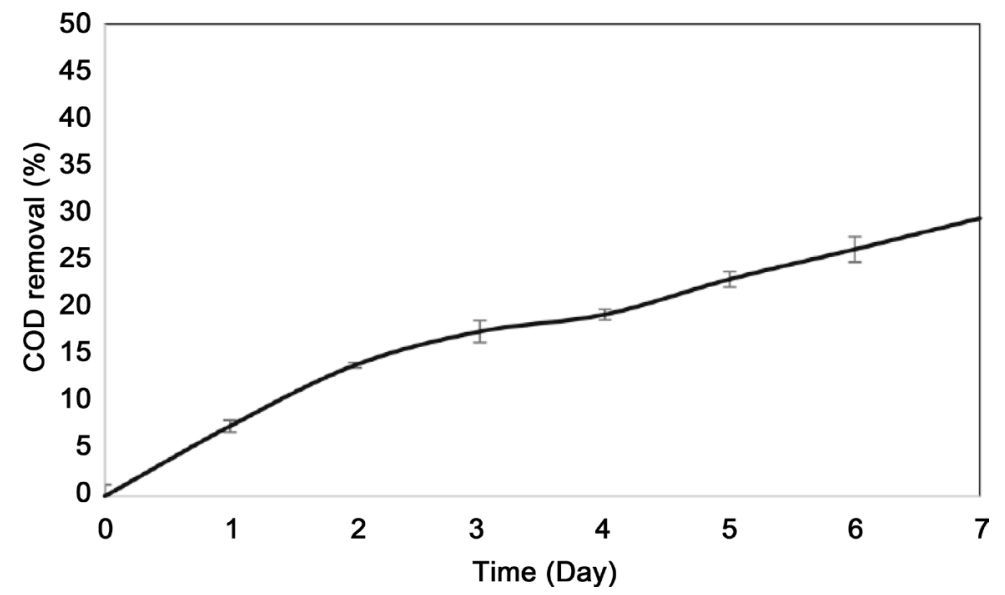

Figure 5. COD removal efficiency within 7 days by SBR system.

Table 3. Removal efficiency of COD from landfill leachate using different biological methods.

\begin{tabular}{|c|c|c|}
\hline initial concentration of COD $(\mathrm{mg} / \mathrm{L})$ & COD removal (\%) & resources \\
\hline \multicolumn{3}{|l|}{ Anaerobic sequencing batch reactor } \\
\hline 17,000 & $64-85$ & {$[11]$} \\
\hline 6000 & 80 & {$[12]$} \\
\hline \multicolumn{3}{|l|}{ Up-flow anaerobic sludge blanket (UASB) } \\
\hline $45,000-90,000$ & 71 & [15] \\
\hline 6000 & 77 & [23] \\
\hline \multicolumn{3}{|l|}{ Moving-bed biofilm reactor (MBBR) } \\
\hline $800-2000$ & 20 & {$[24]$} \\
\hline $7500-7900$ & 8 & {$[25]$} \\
\hline \multicolumn{3}{|l|}{ Membrane bioreactor (MBR) } \\
\hline $1000-3000$ & $80-83$ & [26] \\
\hline 1550 & 63 & {$[20]$} \\
\hline 14,000 & 80 & {$[27]$} \\
\hline \multicolumn{3}{|l|}{ aerobic sequencing batch reactor (ASBR) } \\
\hline 4000 & 87 & {$[21]$} \\
\hline 3200 & 30 & {$[28]$} \\
\hline \multicolumn{3}{|l|}{ Aerated lagoons } \\
\hline 1740 & 75 & {$[22]$} \\
\hline 5518 & 97 & [29] \\
\hline
\end{tabular}

tion [22]. In another study, the use of this method in leachate treatment led to the removal of $97 \%$ COD and $92 \%$ ammonia nitrogen [29]. The COD removal by different biological methods, are listed in Table 3. Because of the fact that the sample of raw leachate was taken from different landfills in variable times, the concentration of COD is different. 


\section{Conclusion}

In this study, various methods of biological treatment of landfill leachate such as anaerobic sequencing batch reactors, aerobic sequencing batch reactors, up-flow anaerobic sludge blanket (UASB), moving-bed biofilm reactor (MBBR), membrane bioreactor (MBR), and aerated lagoons were examined. As mentioned, the minimum and maximum removal of COD by biological reactors were $64 \%$ and $85 \%, 30 \%$ and $87 \%, 71 \%$ and $77 \%, 8 \%$ and $20 \%, 63 \%$ and $83 \%, 75 \%$ and $95 \%$, respectively. According to the results, the highest and lowest removal of COD was achieved by using aerated Lagoon (95\%) and moving-bed biofilm reactor (8\%), respectively.

\section{References}

[1] Peyravi, M., Jahanshahi, M., Alimoradi, M. and Ganjian, E. (2016) Old Landfill Leachate Treatment through Multistage Process: Membrane Adsorption Bioreactor and Nanofitration. Bioprocess and Biosystems Engineering, 39, 1803-1816. https://doi.org/10.1007/s00449-016-1655-0

[2] Tchobanoglous, G., Theisen, H. and Eliassen, R. (1977) Solid Wastes: Engineering Principles and Management Issues. McGraw-Hill, New York.

[3] Abdoli, M.A. and Ghazizadeh, M.J. (2007) Evaluation of the Ability to Adapt New Technologies of Waste Management in the Country. Environmental Studies, 33, 5162.

[4] May-Marrufo, A.A., Mendez-Novelo, R.I., Barceló-Quintal, I.D., Solís-Correa, H.E. and Giacoman-Vallejos, G. (2017) Leachate Treatment by Heterogeneous Fenton on an Activated Carbon Substrate with Fe (II) Impregnated. Journal of Environmental Protection, 8, 524. https://doi.org/10.4236/jep.2017.84036

[5] Primo, O., Rivero, M.J. and Ortiz, I. (2008) Photo-Fenton Process as an Efficient Alternative to the Treatment of Landfill Leachates. Journal of Hazardous Materials, 153, 834-842. https://doi.org/10.1016/j.jhazmat.2007.09.053

[6] Katsifarakis, K.L. (1993) Solar Distillation Treatment of Landfill. A Case Study in Greece. Desalination, 94, 213-221. https://doi.org/10.1016/0011-9164(93)EO130-P

[7] Chonattu, J., Prabhakar, K. and Pillai, H.P.S. (2016) Geospatial and Statistical Assessment of Groundwater Contamination Due to Landfill Leachate-A Case Study. Journal of Water Resource and Protection, 8, 121.

https://doi.org/10.4236/jwarp.2016.82010

[8] Gao, J., Oloibiri, V., Chys, M., Audenaert, W., Decostere, B., He, Y. and Van Hulle, S.W. (2015) The Present Status of Landfill Leachate Treatment and Its Development Trend from a Technological Point of View. Reviews in Environmental Science and Biol Technology, 14, 93-122. https://doi.org/10.1007/s11157-014-9349-Z

[9] Hasar, H., Unsal, S.A., Ipek, U., Karatas, S., Cinar, O., Yaman, C. and Kınac1, C. (2009) Stripping/Flocculation/Membrane Bioreactor/Reverse Osmosis Treatment of Municipal Landfill Leachate. Journal of Hazardous Materials, 171, 309-317. https://doi.org/10.1016/j.jhazmat.2009.06.003

[10] Wiszniowski, J., Robert, D., Surmacz-Gorska, J., Miksch, K. and Weber, J.V. (2006) Landfill Leachate Treatment Methods: A Review. Environmental Chemistry Letters, 4, 51-61. https://doi.org/10.1007/s10311-005-0016-Z

[11] Timur, H. and Özturk, I. (1997) Anaerobic Treatment of Leachate Using Sequenc- 
ing Batch Reactor and Hybrid Bed Filter. Water Science and Technology, 36, 501508. https://doi.org/10.1016/S0273-1223(97)00561-1

[12] Wang, K., Wang, S., Zhu, R., Miao, L. and Peng, Y. (2013) Advanced Nitrogen Removal from Landfill Leachate without Addition of External Carbon Using a Novel System Coupling ASBR and Modified SBR. Bioresource Technology, 134, 212-218. https://doi.org/10.1016/j.biortech.2013.02.017

[13] Renou, S., Givaudan, J.G., Poulain, S., Dirassouyan, F. and Moulin, P. (2008) Landfill Leachate Treatment: Review and Opportunity. Journal of Hazardous Materials, 150, 468-493. https://doi.org/10.1016/j.jhazmat.2007.09.077

[14] Shooshtari, A.A. (2007) Reviewing the Performance of UASB Reactor for Treatment of Municipal Solid Waste Leachate in the Tropical City of Ahvaz.

[15] Govahi, S., Karimi-Jashni, A. and Derakhshan, M. (2012) Treatability of Landfill Leachate by Combined Upflow Anaerobic Sludge Blanket Reactor and Aerated Lagoon. International Journal of Environmental Science and Technology, 9, 145-151. https://doi.org/10.1007/s13762-011-0021-7

[16] Masoum Abad, M.G. and Fard, Z.H.A. (2015) Waste Leachate, Its Strategies and Methods of Treatment. Khanyaran Publications, Tehran.

[17] Metcalf and Eddy (2003) Wastewater Engineering, Treatment and Reuse. McGrawHill, New York.

[18] Iorhemen, O.T., Hamza, R.A. and Tay, J.H. (2016) Membrane Bioreactor (MBR) Technology for Wastewater Treatment and Reclamation: Membrane Fouling. Membranes, 6, 33. https://doi.org/10.3390/membranes6020033

[19] Insel, G., Dagdar, M., Dogruel, S., Dizge, N., Cokgor, E.U. and Keskinler, B. (2013) Biodegradation Characteristics and Size Fractionation of Landfill Leachate for Integrated Membrane Treatment. Journal of Hazardous Materials, 260, 825-832. https://doi.org/10.1016/j.jhazmat.2013.06.037

[20] Zolfaghari, M., Jardak, K., Drogui, P., Brar, S.K., Buelna, G. and Dubé, R. (2016) Landfill Leachate Treatment by Sequential Membrane Bioreactor and Electro-Oxidation Processes. Journal of Environmental Management, 184, 318-326. https://doi.org/10.1016/j.jenvman.2016.10.010

[21] Liu, Z., Wu, W., Shi, P., Guo, J. and Cheng, J. (2015) Characterization of Dissolved Organic Matter in Landfill Leachate during the Combined Treatment Process of Air Stripping, Fenton, SBR and Coagulation. Waste Management, 41, 111-118. https://doi.org/10.1016/j.wasman.2015.03.044

[22] Mehmood, M.K., Adetutu, E., Nedwell, D.B. and Ball, A.S. (2009) In Situ Microbial Treatment of Landfill Leachate Using Aerated Lagoons. Bioresource Technology, 100, 2741-2744. https://doi.org/10.1016/j.biortech.2008.11.031

[23] Wu, L., Zhang, L., Xu, Y., Liang, C., Kong, H., Shi, X. and Peng, Y. (2016) Advanced Nitrogen Removal Using Bio-Refractory Organics as Carbon Source for Biological Treatment of Landfill Leachate. Separation and Purification Technology, 170, 306313. https://doi.org/10.1016/j.seppur.2016.06.033

[24] Welander, U., Henrysson, T. and Welander, T. (1998) Biological Nitrogen Removal from Municipal Landfill Leachate in a Pilot Scale Suspended Carrier Biofilm Process. Water Research, 32, 1564-1570. https://doi.org/10.1016/S0043-1354(97)00351-5

[25] Chen, S., Sun, D. and Chung, J.S. (2008) Simultaneous Removal of COD and Ammonium from Landfill Leachate Using an Anaerobic-Aerobic Moving-Bed Biofilm Reactor System. Waste Management, 28, 339-346. 
https://doi.org/10.1016/j.wasman.2007.01.004

[26] Syron, E., Semmens, M.J. and Casey, E. (2015) Performance Analysis of a PilotScale Membrane Aerated Biofilm Reactor for the Treatment of Landfill Leachate. Chemical Engineering Journal, 273, 120-129.

https://doi.org/10.1016/j.cej.2015.03.043

[27] Boonnorat, J., Techkarnjanaruk, S., Honda, R. and Prachanurak, P. (2016) Effects of Hydraulic Retention Time and Carbon to Nitrogen Ratio on Micro-Pollutant Biodegradation in Membrane Bioreactor for Leachate Treatment. Bioresource Technology, 219, 53-63. https://doi.org/10.1016/j.biortech.2016.07.094

[28] Lim, C.K., Seow, T.W., Neoh, C.H., Nor, M.H.M., Ibrahim, Z., Ware, I. and Sarip, S.H.M. (2016) Treatment of Landfill Leachate Using ASBR Combined with Zeolite Adsorption Technology. Biotech, 6, 195. https://doi.org/10.1007/s13205-016-0513-8

[29] Robinson, H.D. and Grantham, G. (1988) The Treatment of Landfill Leachates in On-Site Aerated Lagoon Plants: Experience in Britain and Ireland. Water Research, 22, 733-747. https://doi.org/10.1016/0043-1354(88)90184-4

\section{Appendix}

\begin{tabular}{cc}
\hline Abbreviation & Explanation \\
\hline BOD & Biological oxygen demand \\
COD & Chemical oxygen demand \\
TOC & Total organic carbon \\
VS & Volatile solids \\
HRT & Hydraulic retention time \\
SRT & Sludge retention time \\
ASBR & Anaerobic sequencing batch reactor \\
SBR & Sequencing batch reactor (aerobic) \\
UASB & Up-flow anaerobic sludge blanket \\
MBBR & Moving-bed biofilm reactor \\
MBR & Membrane bioreactor \\
F/M & Food to microorganism \\
\hline
\end{tabular}


Submit or recommend next manuscript to SCIRP and we will provide best service for you:

Accepting pre-submission inquiries through Email, Facebook, LinkedIn, Twitter, etc. A wide selection of journals (inclusive of 9 subjects, more than 200 journals)

Providing 24-hour high-quality service

User-friendly online submission system

Fair and swift peer-review system

Efficient typesetting and proofreading procedure

Display of the result of downloads and visits, as well as the number of cited articles Maximum dissemination of your research work

Submit your manuscript at: http://papersubmission.scirp.org/

Or contact oje@scirp.org 